\title{
ОБУЧЕНИЯ КИТАЙСКОМУ ЯЗЫКУ РОССИЙСКИХ ДЕТЕЙ ДОШКОЛЬНОГО ВОЗРАСТА ПОСРЕДСТВАМИ ТРАДИЦИОННЫХ ДЕТСКИХ СТИХОВ
}

\section{TEACHING THE CHINESE LANGUAGE TO RUSSIAN PRESCHOOL CHILDREN BY MEANS OF CHINESE TRADITIONAL CHILDREN'S POETRY}

Hu Zhiyuan

Summary: Traditional Chinese nursery rhymes are an important resource for Russian preschoolers to learn Chinese. They can help preschoolers learn Chinese pronunciation quickly and understand the meaning of words. Educators can combine observation images, theatrical performances, and other techniques so that children can recognize characters, understand characters' actions, perceive specific colors, learn appropriate nouns, verbs, and adjectives using traditional nursery rhymes, and enhance the enjoyment of learning Chinese. Promote the language development of preschoolers.

Keywords: traditional nursery rhymes, children's literature, preschoolers, Chinese, strategies.
Ху Чжиюань

аспирант, Южно-Уральский государственный гуманитарно-педагогический университет (г. Челябинск) huzhiyuan@yandex.ru

Аннотация: Традиционные китайские детские стишки - важный ресурс для изучения китайского языка российскими дошкольниками. Они могут помочь дошкольникам быстро освоить китайское произношение и понять значение слов. Педагоги могут комбинировать изображения наблюдений, театральные представления и другие методы, чтобы дети могли узнавать персонажей, понимать действия персонажей, воспринимать определенные цвета, выучивать соответствующие существительные, глаголы и прилагательные с помощью традиционных детских стишков и повышать удовольствие от изучения китайского языка. Содействовать языковому развитию дошкольников.

Ключевые слова: традиционные детские стишки, детская литература, дошкольники, китайский язык, стратегии.
$\mathrm{B}$ Китае традиционные детские стишки являются старейшей формой детской литературы с более чем тысячелетней историей. Поколения китайцев унаследовали и распространяли их в устной речи. Известный писатель детской литературы и исследователь стишков Цзинь Бо сказал: «В древнем Китае были учреждения и отдельные лица, специализирующиеся на сборе детских стишков и народных сказок. Были сборники детских стишков в династиях Мин и Цин в Китае. Шанхайская всемирная книжная компания в 11-м году существования Китайской Республики также публиковала «Великий взгляд на рисование детских стишков», собрание из почти 300 детских стишков со всего Китая, составленных в четыре тома, с большими буквами и красивыми иллюстрациями». [1, с. 57]

После сбора и сортировки групп китайских ученых более 1000 были широко распространены по всему Китаю. Первый детский стишок.

Эти традиционные детские стишки также являются важными ресурсами в процессе обучения китайскому языку российских дошкольников. Эти традиционные детские стишки - первые примеры того, как дошкольники изучают китайский язык и становятся ближе к китайскому. Они являются лучшим способом для детей учиться и понимать общество. Они очень важны для чувствительности детского слуха, ритма и ритма.

\section{1. Важная шенность изучения китайского языка с помошью трацишионных Аетских стишков}

Ритм детской литературы прежде всего отражается в фонетическом аспекте. Традиционные детские стишки - это детские литературные произведения, в которых фонетический ритм является первым эстетическим элементом. Его ритмические характеристики отражаются во всех аспектах фонетики, включая ритмические эффекты рифмы, двойного тона, повторения и цепочки, а также двойственности. Параллелизм, петли, повторение и другие структурные просодические эффекты. [2, с. 87] В традиционных детских стишках, скороговорках, цепных мелодиях, песнях-викторинах и других типах большинство из них одновременно используют вышеупомянутые ритмические техники. Их огибающие, четкий ритм и запоминающиеся рифмовые характеристики позволяют дошкольникам понимать эти песни как можно раньше. Я уже запомнил его язык до его значения, что, очевидно, будет способствовать изучению китайского.

Детская литература хороша в объяснении или представлении определенного объекта, такого как назва- 
ние, концепция и характер вещей, визуально, близким к способности понимания детей. Многие знания, которые трудно объяснить понятным детям языком, были ярко объяснены и переданы в детской литературе. [3, с. 126] Традиционные детские стишки включают воспевание большого количества вещей в повседневной жизни, включая такие природные явления, как солнце, луна, звезды, ветер, дождь, гром и электричество, а также базовые знания о различных животных и растениях. В детских стихотворениях также есть числа, цвета, пространство, время и так далее. Изучение традиционных детских стишков помогает детям хранить все более расширяемый «мысленный словарь» лексики и моделей предложений. Во время повторного прослушивания речи и речи он постоянно активирует импульсы восприятия речи в коре головного мозга детей, чтобы дети могли понимать язык. Соответственно ширина, глубина и чувствительность постоянно улучшались. [4, с. 54]

\section{2. Подбор и анализ традичионных Аетских стишков}

В Китае за последние десять лет известные художники создали ряд прекрасных книг с большим количеством картинок на основе традиционных детских стишков. Рисунки наглядно объясняют содержание традиционных детских стишков и помогают детям лучше понимать детские стишки. Вещи описываются, понимают свои эмоции и состояния. Среди выдающихся - «Живут овощи в огороде» и «Дедушка Мышонок дома?» 、 «Луна Баба» .

\section{1 «Овоши в огороде живые»}

«Овощи в огороде в прямом эфире» - это традиционный детский стишок, широко распространенный в северном Китае. Художник Сюн Лян создал для него много картинок. Он был опубликован в Народном издательстве Тяньцзиня в июле 2017 года, и было продано более 100000 экземпляров. книга. Всего в книге 24 страницы, каждая страница имеет относительно большое пространство для картинок, а текст состоит всего из одной или двух строк. Основное содержание детского стишка: овощи в огороде оживали один за другим. Редис и корень лотоса побуждали своих партнеров драться в огороде. Овощи, такие как зелень, редис, ростки фасоли, капуста, зеленый лук и другие овощи, использовали сами по себе. В конце концов тыква поставила пушку, и чеснок сломал ее лепестки, огурцы посинели, перец стал красным, а баклажаны стали пурпурными. Наконец корню лотоса пришлось отступить и сбежать в пруд. , С тех пор живет в пруду.

\section{2 «АеАушка Мышь $\triangle 0 м а ? »$}

«Дедушка Мышь дома?» Это традиционный детский стишок, который особенно популярен в Пекине, Китай.
Художник Нянь Чжоу Сян нарисовал вокруг той работы, превратив детский стишок в книгу, и опубликовал ее в издательстве 2012 году. Основное содержание этого детского стишка: «Сейчас час, и кошка ловит мышь. День длинный, ночь коротка, Дедушка Мышонок встает поздно». После этого читается от «2 часов» до «10 часов». Кошка все время спрашивала: «Дедушка Мышь дома?» A «Мышь» всегда отвечал, что делает, и не выходил из дома. Это веселый детский стишок в форме одного вопроса и одного ответа, он показывает взаимодействие семьи кошки и мышки, как игра, в которую играют дети. [5, c. 213]

\section{3 «^унный Баба»}

«Лунный баба» - самый распространенный детский стишок в городе Чанша, провинция Хунань. Художник Цай Гао рисует изображения вокруг содержания детских стишков. Эта книга была опубликована Детским издательством Хунань в июне 2016 года. Основное содержание детского стишка: есть старый дедушка, живущий на луне. Когда старый дед выходит купить еды, там еще живет бабушка. Когда выходит бабушка, в нем живет девочка. Когда девочка вышивает, она вышивает после папы, папа упал в колодец и превратился в жабу. Жаба забралась на дерево и стала сорокой, а сорока забралась на дерево и стала горлицей ... «В детских стишках папа - это торт, а торт - любимый китайский пирог. Праздничный подарок.»

\section{3. Стратегии применения традиционных Аетских стишков к обучению

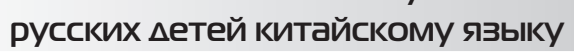

\section{1 С помошью картинок в книге узнайте о персонажах и сушествительных}

Эти традиционные детские стишки стали более интуитивно понятными и яркими благодаря творчеству художника. Художник рисует очень специфических и типичных персонажей, основываясь на собственном жизненном опыте и художественном мастерстве. [6] Например «Дедушка Мышонок дома?» В основном вращается вокруг мышей и кошек. Постоянно повторяя, дети должны быстро освоить роль «мыши» и запомнить это китайское слово. Если вы воспользуетесь картинками из книги, дети будут помнить выражения мышки каждый раз, когда они будут отвечать, и они смогут понять юмор и интерес к детской литературе. Обучаясь через сочетание слов и картинок, дети приобретают не только память, но и понимание, понимание значения слов, которые нужно выразить, что очень важно для изучения китайского языка.

Так, например в «Овощи в огороде живые» дети не только выучили слово «зеленая луковица», но и увидели 
в книге яркое изображение зеленого лука: зеленая талия прямая, как ружье. В «Лунной бабе» дети почувствуют и поймут красоту «Луны». [7]

\section{2 Через выступ^ения понять $\Delta$ вижения персонажей и выучить глаголы}

Детские литературные произведения, созданные для детей, обычно содержат много действий персонажей, а некоторые даже используют действия персонажей, чтобы способствовать развитию содержания. [8, с. 98]. То же самое и с детскими стишками: некоторые действия повторяются: слушая детские стишки, читаемые взрослыми, дети могут внимательно наблюдать за содержанием картинок, понимать характерные особенности персонажей и затем исполнять их. Обучаясь на собственном опыте, дети будут лучше воспринимать и понимать значение слов. Благодаря большему участию весь процесс обучения не будет скучным, а интерес к изучению китайского языка только возрастет. [9, с. 135]

Например, в «Лунной бабе» мы можем позволить дошкольникам научиться «меняться», этот глагол появляется в каждом предложении, и каждый раз, когда «изменить», это удивит детей. Одно за другим следующее событие связано с действием предыдущего персонажа, что особенно удобно для детей. В процессе обучения учитель может сначала продемонстрировать произношение глагола «изменить», а затем постепенно побудить детей произносить слово «изменить» при изменении содержания. Этот глагол ведет к изменению сюжетной ситуации, и ребенок ощутит волшебство «перехода» на это слово.

В «Дедушка Мышь дома?» дети могут выучить и выполнять множество различных действий: полоскать рот, умываться, пить чай, есть десерт, есть, чистить зубы, ходить и другие разные глаголы.

На рисунках художник показал характеристики каждого действия, предоставив детям основные модели поведения и указания для их интерпретации.

\section{3 Через рисование узнайте швет вешей и выучите прилагательные}

Традиционные детские стишки играют богатую и красочную роль. В выражении слов они часто используют богатые описательные слова для их описания, такие как толстый, худой, высокий, низкий, черный, белый, яркий и темный. [10, с. 85] При обучении детей изучению китайского словарного запаса прилагательных посредством чтения детской литературы его также можно комбинировать со способом рисования, чтобы дети дошкольного возраста могли сами наблюдать и воспринимать цвет и форму предметов и делать их более подробными и всеобъемлющими. Знайте, понимайте и запоминайте эти описательные слова.

Например, «Овощи в огороде Live» финал детской стишки очень юмористический: тыква поставила пушку, чеснок треснул лепестки, огурцы стали зелеными, перец стал красным, а баклажаны целыми пурпурный. Если вы хотите научить дошкольников выучить цветные прилагательные, такие как «красный», «фиолетовый», «голубой» и т. Д., Вы можете подготовить черно-белые картинки с перцами, баклажанами, огурцами и другими овощами для каждого ребенка и попросить их раскрасить картинки цветами. Перед раскраской учитель может рассказать детям китайские прилагательные о цветах, таких как «красный», «фиолетовый» и «голубой».

Если дошкольникам разрешено запоминать китайские слова механически с помощью традиционного и утомительного метода «грамотности-запоминания», им может быть скучно и скучно, и их особенно легко забыть после изучения, они не могут понять и даже не могут выучить словарный запас. Используется в реальной жизни. [11] Изучение китайского языка с помощью традиционных детских стишков может вызвать у детей дошкольного возраста радость обучения. Они не будут ненавидеть китайские слова, потому что знают, что эти слова взяты из интересных детских стишков или рассказов, и то, что они видят, не является абстрактным. С помощью произведений они смогут понять значение слов, а посредством демонстрации традиционных детских стишков они постепенно усвоят правила использования языка. Это очарование детской литературы, важный путь для дошкольников выучить китайский язык.

\section{Приложение: Обложка книги традиционных

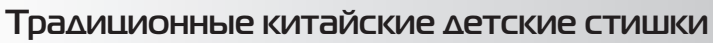

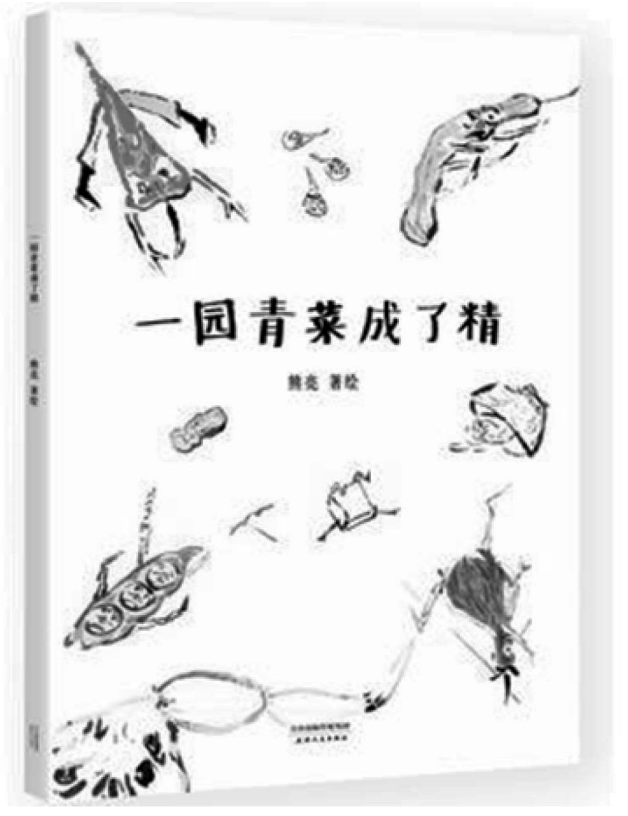



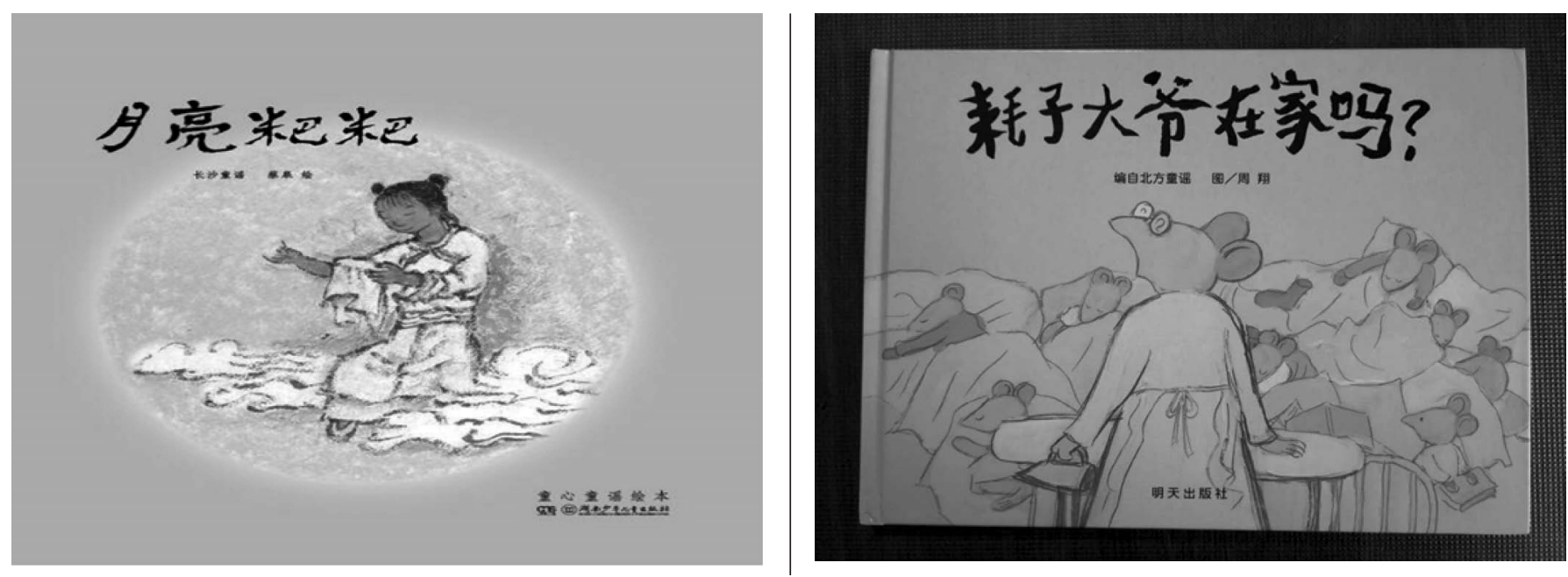

\section{ЛИТЕРАТУРА}

1. Чжу Юнсинь. Базовая библиография для китайских учеников начальной школы. М.: Издательство Народного университета Китая, 2013.С. 353.

2. Фан Вэйпин. Курс детской литературы. М.: Издательство Фуданьского университета, 2015.С. 407.

3. Вэй Вэй. История мировой детской литературы. М.: Издательство Образование провинции Аньхой, 2013.С. 842.

4. Гуй Шичун. Новая психолингвистика. М.: Шанхайское издательство иностранных языков, 2000.С. 679.

5. Пэн И. Всемирная книжка с картинками, чтение и классика. М.: Издательство реле, 2011.С. 321.

6. Ц Юю Юаньтин. Между миллиметром и сантиметром // Южный народный еженедельник. 2020. № 9. C. 15-18. URL: https://www.nfpeople.com/article/9900.

7. Ян Лиин. Исследование книги с картинками Сюн Ляна в китайском стиле //магистерская работа Чжэцзянского педагогического университета. 2016. URL:http://gb.oversea.cnki.net/KCMS/detail/detailall.aspx?filename=1016289351.nh\&dbcode=CMFD\&dbname=CMFDREF.

8. У Уинань. От церемонии до карнавала: исследование творчества детских писателей XX века. М.: Издательство народной литературы., $2014 . C .336$.

9. Чжан Минхун. Специалист по языковому образованию и планированию деятельности в детском саду. М.: Издательство Восточно-Китайского педагогического университета, 2014.С. 260.

10. Ли Имань. Сопровождает детей в течение шести лет до школы. М.: Издательство Пекинского университета, 2013.С.197.

11. Чжоу Цзин, Чжоу Цзин. Учить детей читать лучше, чем читать книжки с картинками. //Китайская молодежная газета. 14.7.2017.

(c) Ху Чжиюань (huzhiyuan@yandex.ru). 